\title{
Diethyl Selenodiglycolate: An Eco-Friendly Synthetic Antioxidant with Potential Application to Inflammatory Disorders
}

\author{
Marcos F. Pinatto-Botelho, ${ }^{\oplus a, b}$ Railmara P. da Silva, ${ }^{c}$ Marcos V. L. R. Archilha, ${ }^{a, b}$ \\ Lilian Giroldo, ${ }^{a}$ Aleksey E. Kuznetsov, ${ }^{d}$ Flávia C. Meottic and Alcindo A. dos Santos ${ }^{\circledR} * a$ \\ ${ }^{a}$ Departamento de Química Fundamental, Instituto de Química, Universidade de São Paulo, \\ 05508-000 São Paulo-SP, Brazil \\ ${ }^{b}$ SelenoLife, Centro de Inovação, Empreendedorismo e Tecnologia (CIETEC), \\ Instituto de Pesquisas Energéticas e Nucleares (IPEN), Universidade de São Paulo, \\ 05508-000 São Paulo-SP, Brazil \\ 'Departamento de Bioquímica, Instituto de Química, Universidade de São Paulo, \\ 05508-000 São Paulo-SP, Brazil \\ ${ }^{d}$ Department of Chemistry, Universidad Técnica Federico Santa Maria, \\ Av. Santa Maria 6400, Vitacura, 7660251 Santiago, Chile
}

\begin{abstract}
This study describes a single step, high yield and purity, ecofriendly and scalable procedure to prepare a selenium derivative (diethyl selenodiglycolate). Diethyl selenodiglycolate rapidly reduces hypochlorous acid ( $\mathrm{HOCl}$, second-order rate constant of $7 \times 10^{7} \mathrm{M}^{-1} \mathrm{~s}^{-1}$ ) to generate its corresponding selenoxide. In activated HL-60 cells, diethyl selenodiglycolate selectively reacted with $\mathrm{HOCl}$ (half maximal inhibitory concentration $\left(\mathrm{IC}_{50}\right)=23.07 \mu \mathrm{M}$ ) but not with superoxide anion radical or hydrogen peroxide without any cytotoxicity. These results show that this synthetically simple selenide reacts in a very efficient and specific way with the harmful pro-oxidant $\mathrm{HOCl}$ being a promising compound to be applied in oxidative inflammatory-related conditions.
\end{abstract}

Keywords: diethyl selenodiglycolate, antioxidant, inflammation, oxidative burst, hypochlorous acid

\section{Introduction}

Selenium is well recognized as an essential micronutrient for living organisms. Its major biological benefits are, mostly, associated to the trapping ability of endogenous oxidant entities and modulation of redox processes. ${ }^{1}$ These features are consequences of unique properties of selenium. Hence, some biomolecules evolved to incorporate selenium instead of sulfur because of its lower reduction potential besides enhanced nucleophilic capacity, among other characteristics that make it unique. ${ }^{2,3}$ In 1973, Turner and Stadtman ${ }^{4}$ identified the bacterial glycine reductase as the first specific selenoprotein to be discovered, and consequently selenocysteine, the selenium-containing amino acid component of this protein, was baptized as the $21^{\text {st }}$ natural amino acid.

\footnotetext{
*e-mail: alcindo@iq.usp.br
}

Now, about 44 years later, it is known that selenium is present in a range of selenoproteins ${ }^{2}$ and each one plays important roles in endogenous biological events of animals in which they are present.

Although not considered essential for plants, ${ }^{5,6}$ the natural occurrence of selenium in some plants is a result of its incorporation from the mineral form present in soil, and this plant-selected chemical speciation is a well intricate stratagem of the nature to contribute to the evolution process involving this element and the maintenance of life.

Despite all the knowledge about this element that we have today and its participation in life, the early scenarios involving selenium in living organisms were accompanied by many misunderstandings, doubts and folklores. The chemical properties of the first organic compounds of selenium and its chalcogen partner, tellurium, were deeply associated to bad things specially because of their low stability in presence of air and light and the repulsive bad smelling of their low weight derivatives. ${ }^{7}$ Since the first 
reports involving the preparative chemistry of selenium, an enormous number of new synthetic strategies, reagents and chemical procedures involving this element were developed which leads us to the possibility of producing a very large number of selenium-containing organic compounds nowadays. ${ }^{8}$

Selenium-containing compounds have been designed and synthesized based on its oxidant trapping capacity. They can act promoting the redox cell homeostasis in the human organisms. ${ }^{9}$ An example of the most known synthetic compound that can counteract oxidant species is Ebselen, which possesses high antioxidant ${ }^{10}$ and neuroprotective activity. ${ }^{11}$ The antioxidant ability of Ebselen is related to the glutathione peroxidase-like (GPx) activity. ${ }^{12}$ More recently, analogs of Ebselen were synthesized in order to enhance the GPx-like activity; some of them achieved an activity ten times higher. ${ }^{13}$ Similar activities were presented by a camphor based selenamide derivative ${ }^{14}$ and some water soluble selenides, presenting different ring sizes and organic chemical functionality classes. ${ }^{15}$ Organoselenium compounds which act against lipid peroxidation, free radical chain reaction ${ }^{16}$ and possess pharmacological properties have been extensively investigated. ${ }^{17,18}$ In fact, the hypohalous acid-scavenging efficiency of some synthetic selenium-containing compounds, including selenomethionine, has been described. ${ }^{19-21}$ Seleno-talitol, seleno-iditol, seleno-gulose and seleno-mannose reacted with hypohalous acids with a constant rate comparable to those of glutathione $\left(1.1 \times 10^{8} \mathrm{M}^{-1} \mathrm{~s}^{-1}\right) \cdot{ }^{19}$ Even with the promising activity, the synthesis of these compounds are experimentally tedious, involving high costing steps that limit their potential usage and application. Therefore, we sought a simpler method to prepare redox active selenocarboxylic acid derivative that could be employed as antioxidants. We performed a green, single-step synthesis of a low-weight selenide. The scavenger effect of the molecule toward hypochlorous acid was proved by kinetic approach and by identification of the reaction products. In addition, we evaluated the efficiency of the compound to neutralize selectively hypochlorous acid to the detriment of other oxygen metabolites produced by HL-60 cells in an inflammatory burst condition.

\section{Experimental}

Hydrogen $\left({ }^{1} \mathrm{H}\right)$, carbon $\left({ }^{13} \mathrm{C}\right)$ and selenium $\left({ }^{77} \mathrm{Se}\right)$ nuclear magnetic resonance spectra (NMR) were recorded on a Bruker AVANCE III $200 \mathrm{MHz}$ spectrometer in the appropriate solvents. Chemical shifts $(\delta)$ were reported in parts per million (ppm), relative to the internal standard, tetramethylsilane or diphenyl diselenide $\left(\mathrm{Ph}_{2} \mathrm{Se}_{2}\right)$. The multiplicity of each signal is indicated by s (singlet), ls (large singlet), d (doublet), t (triplet), q (quartet), $\mathrm{dd}$ (doublet of doublets), dt (doublet of triplets) and $\mathrm{m}$ (multiplet). The number of hydrogens (n) for a given resonance is indicated by $\mathrm{nH}$ and coupling constants $(J)$ are quoted in $\mathrm{Hz}$.

High-resolution mass spectrometry (HRMS) was performed on q-ToF maxis 3G Bruker Daltonics, with electrospray ionization (ESI). GC-MS-EI analyses (gas chromatography-mass spectrometry-electron impact) were performed on a Shimadzu GC/MS-QP2010 equipped with Rtx-5MS column, using helium as carrier gas. Analytical ultra pressure liquid chromatography (UPLC) was performed with a Shimadzu Nexera instrument equipped with Shim-pack XR-ODS (Shimadzu, $100 \times 2.3 \mathrm{~mm}$, $2.2 \mu \mathrm{m}$ ) column at $40{ }^{\circ} \mathrm{C}$ and $0.6 \mathrm{~mL} \mathrm{~min}{ }^{-1}$ flow.

Reagents fetal bovine serum was purchased from VitroCell (Campinas, Brazil), Amplex ${ }^{\circledR}$ Red was purchased from Life Technologies (Burlington, Canada). Other reagents including elemental selenium, sodium borohydride, ethyl chloroacetate, ethyl acetate, magnesium sulfate, deuterated chloroform, $\mathrm{Ph}_{2} \mathrm{Se}_{2}$, L-methionine, dichloromethane, calcium hydride, trimethylsilyl chloride, deuterated dimethyl sulfoxide, $N, N$-di-isopropylethylamine, 9-fluorenylmethoxycarbonyl chloride, diethyl ether, sodium bicarbonate, hydrochloric acid $(\mathrm{HCl}), \mathrm{NaOCl}$ (sodium hypochlorite), methanol (MeOH), tetrahydrofuran (THF), sodium acetate $(\mathrm{NaOAc})$, cell culture materials Roswell Park Memorial Institute (RPMI) 1648, penicillin and streptomycin, 5-thio-2-nitrobenzoic acid (TNB), taurine, cytochrome c, peroxidase from horseradish (HRP), magnesium chloride $\left(\mathrm{MgCl}_{2}\right)$, calcium chloride $\left(\mathrm{CaCl}_{2}\right)$, propidium iodide (PI), phorbol myristate acetate (PMA) and staurosporin were purchased from Sigma-Aldrich (Darmstadt, Germany) and when necessary, purifications were performed according to specific conditions. ${ }^{22}$ Hypochlorous acid ( $\mathrm{HOCl})$ quantification was determined at $\varepsilon_{292 \mathrm{~nm}}$ (molar absorptivity at $292 \mathrm{~nm}$ ) $=350 \mathrm{~L} \mathrm{~mol}^{-1} \mathrm{~cm}^{-1}{ }^{23}$ The competitive kinetic analyses were performed in $10 \mathrm{mmol} \mathrm{L}^{-1}$ phosphate buffer solutions $(\mathrm{pH}=7.4$, using $\mathrm{Na}_{2} \mathrm{HPO}_{4}$ (disodium hydrogen phosphate), and $\mathrm{KH}_{2} \mathrm{PO}_{4}$ (potassium dihydrogen phosphate)).

\section{Synthesis of diethyl selenodiglycolate}

To a suspension of elemental selenium $(1.0 \mathrm{~g}$; $12.6 \mathrm{mmol}$ ) in $\mathrm{H}_{2} \mathrm{O}$ (water, $10 \mathrm{~mL}$ ), under nitrogen atmosphere, it was added an aqueous solution of sodium borohydride ( $1.0 \mathrm{~g} ; 26.5 \mathrm{mmol}$, in $10 \mathrm{~mL}$ of $\mathrm{H}_{2} \mathrm{O}$ ). Neat ethyl chloroacetate $(3.08 \mathrm{~g} ; 25.2 \mathrm{mmol})$ was dropwise added to the previously prepared solution of the selenium 
nucleophile, at room temperature. After 30 min under stirring, ethyl acetate $(25 \mathrm{~mL})$ was added to the solution. After few minutes under stirring, the organic phase was collected, dried using magnesium sulfate and filtered. The solvent was removed under reduced pressure to give the diethyl selenodiglycolate as a yellow oil ( $3.2 \mathrm{~g}$; $90 \%$ yield). ${ }^{1} \mathrm{H}$ NMR (200 MHz, $\mathrm{CDCl}_{3}-d$, deuterated chloroform) $\delta 4.22(\mathrm{q}, J 7.1 \mathrm{~Hz}, 2 \mathrm{H}), 3.41$ (s, 2H), $1.32(\mathrm{t}, J 7.1 \mathrm{~Hz}, 3 \mathrm{H})$; ${ }^{13} \mathrm{C} \mathrm{NMR}\left(50 \mathrm{MHz}, \mathrm{CDCl}_{3}\right) \delta 170.76,61.24,23.50,13.98$; ${ }^{77} \mathrm{Se}\left(38 \mathrm{MHz}, \mathrm{CDCl}_{3}\right) \delta 244.7\left(\mathrm{Ph}_{2} \mathrm{Se}_{2}, 461 \mathrm{ppm}\right.$, internal standard); GC-MS-EI $m / z: 254,208,181,153,125,88,60$ (Supplementary Information (SI) section). ${ }^{24}$

\section{Synthesis of Fmoc-methionine}

To a suspension of finely divided L-methionine (L-Met, $1.1 \mathrm{~g} ; 7.5 \mathrm{mmol})$ in dry dichloromethane $(18 \mathrm{~mL})$, under nitrogen atmosphere was added, in a single portion, freshly distilled trimethylsilyl chloride ( $1.29 \mathrm{~g} ; 5 \mathrm{mmol})$. Next, the solution was heated to reflux for $1 \mathrm{~h}$, then the temperature was lowered to $5^{\circ} \mathrm{C}$. $\mathrm{N}, \mathrm{N}$-Di-isopropylethylamine $(1.68 \mathrm{~g}$; $2.26 \mathrm{~mL} ; 13 \mathrm{mmol}$ ) was added to the solution, followed by 9 -fluorenylmethoxycarbonyl chloride (Fmoc-Cl; $1.29 \mathrm{~g} ; 5 \mathrm{mmol}$ ). The mixture was stirred for $90 \mathrm{~min}$ at room temperature. The volatiles were removed by vacuum and the crude reaction mixture was diluted with diethyl ether $(40 \mathrm{~mL})$ followed by sodium bicarbonate $\left(50 \mathrm{~mL}, 2.5 \% \mathrm{~m} \mathrm{~m}^{-1}\right)$. Phases were separated, and the aqueous phase was acidified with hydrochloric acid $(\mathrm{HCl})$ solution $\left(1 \mathrm{~mol} \mathrm{~L}^{-1}\right)$ and then, extracted with ethyl acetate $(3 \times 15 \mathrm{~mL})$. The combined organic phases were dried using sodium sulfate, filtered and solvents were removed under reduced pressure to yield the Fmoc-protected amino acid (Fmoc-Met) in $80 \%$ yield. ${ }^{1} \mathrm{H}$ NMR $\left(200 \mathrm{MHz}\right.$, DMSO- $d_{6}$, deuterated dimethyl sulfoxide) $\delta 12.7(\mathrm{ls}, 1 \mathrm{H}), 8.00-7.30$ (m, 8H), 4.44-3.99 (m, 4H), 2.07 (s, 3H), 1.90 (m, 2H); ${ }^{13} \mathrm{C}$ NMR (50 MHz, DMSO- $\left.d_{6}\right) \delta 174.18,156.64,144.25$, 144.17, 141.14, 128.05, 127.47, 125.66, 120.50, 66.01, $53.09,47.09,30.75,30.26,14.91$ (SI section). ${ }^{25}$

\section{Competitive kinetic for $\mathrm{HOCl}$}

The second order rate constant of the reaction of diethyl selenodiglycolate with $\mathrm{HOCl}$ was calculated from the competition reaction between $\mathrm{NaOCl}$ (sodium hypochlorite) and Fmoc-methionine (Fmoc-Met), according to the procedure already reported. ${ }^{19}$ The reactions were performed at $22{ }^{\circ} \mathrm{C}$, in phosphate buffer $\mathrm{pH}$ 7.4. $\mathrm{NaOCl}$ solution $\left(50 \mu \mathrm{mol} \mathrm{L}^{-1}\right)$ was incubated with Fmoc-Met $\left(250 \mu \mathrm{mol} \mathrm{L}^{-1}\right)$ in presence or absence of diethyl selenodiglycolate $(60-1200 \mu \mathrm{mol} \mathrm{L}-1)$. The proportion of
Fmoc-Met and its oxidation product, Fmoc-methionine sulfoxide (Fmoc-MetSO), was measured by UPLC. Fmoc-Met and Fmoc-MetSO were quantified by UPLC analyses using $75 \%$ phase $\mathrm{B}: 25 \%$ phase A as eluent during $12 \mathrm{~min}$. The phase A consisted of a solution of methanol $(\mathrm{MeOH})(20 \%)$, tetrahydrofuran (THF) $(2.5 \%)$, sodium acetate $(\mathrm{NaOAc})$ sol. $\left(5 \%, \mathrm{pH} 5.3,1 \mathrm{~mol} \mathrm{~L}^{-1}\right)$ and $\mathrm{H}_{2} \mathrm{O}$ (72.5\%), while phase $\mathrm{B}$ was composed of $\mathrm{MeOH}(80 \%)$, THF (2.5\%), NaOAc sol. (5\%, pH 5.3, $1 \mathrm{~mol} \mathrm{~L}^{-1}$ ), and $\mathrm{H}_{2} \mathrm{O}(12.5 \%)$. The samples were filtered before analyses $(0.2 \mu \mathrm{m}$, with $5 \mu \mathrm{L}$ injected in each run) in order to remove any solid still in suspension. Fmoc-MetSO was monitored using photo-diode array detector (PDA) composed by deuterium and tungsten lamp. Under these conditions, Fmoc-MetSO presented a retention time of $0.73 \mathrm{~min}$ and Fmoc-Met, $1.13 \mathrm{~min}$. The peak areas were integrated using Lab Solutions 5.51 software.

The oxidation of Fmoc-Met to Fmoc-MetSO (sulfoxide) was quantified for each concentration of diethyl selenodiglycolate (yield scavenger $_{\text {) }}$ and compared to the maximum yield in the absence of diethyl selenodiglycolate $\left(\right.$ yield $\left._{\max }\right)$. Yields were given by the equation 1 and rearranged according to a linear fitting equation $(y=b x+a)$ (equation 2).

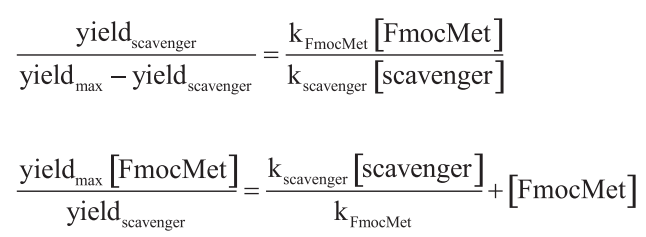

where $\mathrm{k}_{\text {FmocMet }}$ and $\mathrm{k}_{\text {scavenger }}$ are the kinetic constant of the reaction of $\mathrm{HOCl}$ with Fmoc-Met and diethyl selenodiglycolate, respectively; [FmocMet] and [scavenger] are the concentrations of Fmoc-Met and diethyl selenodiglycolate, respectively.

Through the graphical projection [FmocMet] yield $_{\max } /$ yield $_{\text {scavenger }}$ versus the concentration of diethyl selenodiglycolate, it was obtained the tangent line that corresponds to the value of $\mathrm{k}_{\text {scavenger }}(\mathrm{k}$ for $\mathrm{HOCl}$ reaction with the diethyl selenodiglycolate), using the known value of $\mathrm{k}_{\text {FmocMet }}\left(1.3 \times 10^{8} \mathrm{M}^{-1} \mathrm{~s}^{-1}\right)$. The intercept on the $y$ axis corresponds to the value [FmocMet]. ${ }^{19}$

\section{Cell culture}

The human promyelocytic cells (HL-60; Banco de Células do Rio de Janeiro (BCRJ), Duque de Caxias, RJ, Brazil) were maintained in RPMI 1640 culture media supplemented with fetal bovine serum (FBS 20\%), streptomycin $\left(100 \mu \mathrm{g} \mathrm{mL}^{-1}\right)$ and penicillin $\left(100 \mathrm{U} \mathrm{mL}^{-1}\right)$ in 
humid atmosphere at $37{ }^{\circ} \mathrm{C}$ with $5 \%$ carbon dioxide. The desired concentration of HL-60 cells was differentiated in neutrophils (dHL-60) by the addition of dimethyl sulfoxide $(1.3 \%)$ in the same media, but supplemented with $10 \%$ FSB. Cells were maintained in this media for four days. For the experiments, cells were centrifuged at $1400 \mathrm{rpm}$ for $10 \mathrm{~min}$, washed twice with sterile saline sol. ( $0.9 \%$ sodium chloride, $\mathrm{NaCl}$ ) and suspended in phosphate buffer solution (PBS)/ glucose sol. (10 mmol L-1 $\mathrm{Na}_{2} \mathrm{HPO}_{4}, 2 \mathrm{mmol} \mathrm{L}-1 \mathrm{KH}_{2} \mathrm{PO}_{4}$, $137 \mathrm{mmol} \mathrm{L}^{-1} \mathrm{NaCl}, 1 \mathrm{mmol} \mathrm{L}{ }^{-1} \mathrm{CaCl}_{2}, 0.5 \mathrm{mmol} \mathrm{L}^{-1}$ $\mathrm{MgCl}_{2}, 1 \mathrm{~g} \mathrm{~L}^{-1}$ glucose).

\section{Superoxide anion radical}

Differentiated HL-60 cells $\left(1 \times 10^{6}\right)$ were incubated with taurine $\left(5 \mathrm{mmol} \mathrm{L}^{-1}\right)$, in the absence or presence of different concentrations of diethyl selenodiglycolate $(0.5$, $1.0,10,25$ or $50 \mu \mathrm{mol} \mathrm{L} \mathrm{L}^{-1}$ ), in $300 \mu \mathrm{L}$ of PBS/glucose sol. at $37^{\circ} \mathrm{C}$. Cells were activated with PMA (phorbol 12-myristate 13 -acetate, $100 \mathrm{ng} \mathrm{mL}^{-1}$ ) solution, gently homogenized and the superoxide was quantified by the reduction reaction of cytochrome $\mathrm{c}\left(40 \mu \mathrm{mol} \mathrm{L}{ }^{-1}\right) \cdot{ }^{26} \mathrm{In}$ this reaction, the superoxide anion is an electron donor, and iron core of heme group of cytochrome $\mathrm{c}$ is reduced to $\mathrm{Fe}^{2+}$. The amount of reduced cytochrome $\mathrm{c}$ was determined by measuring its absorbance at $550 \mathrm{~nm}$ in a microplate reader (BioTek Synergy H1 Hybrid reader) for $30 \mathrm{~min}$. The rate of superoxide production was quantified by the slope of the increasing absorbance at $550 \mathrm{~nm}$, $\varepsilon_{550 \mathrm{~nm}}=21,000 \mathrm{~L} \mathrm{~mol}^{-1} \mathrm{~cm}^{-1}$.

Hydrogen peroxide $\left(\mathrm{H}_{2} \mathrm{O}_{2}\right)$

The production of hydrogen peroxide $\left(\mathrm{H}_{2} \mathrm{O}_{2}\right)$ was measured by the oxidation of Amplex $\operatorname{Red}^{\oplus}\left(50 \mu \mathrm{mol} \mathrm{L}{ }^{-1}\right)$ in presence of horseradish peroxidase (HRP; $\left.10 \mu \mathrm{mol} \mathrm{L}^{-1}\right){ }^{26}$ Cells were in the same conditions as above. The oxidation of Amplex Red by HRP in the presence of $\mathrm{H}_{2} \mathrm{O}_{2}$ produces the fluorescent product, resorufin (monitored at $550 \mathrm{~nm}$ for $30 \mathrm{~min}$ ). The rate of $\mathrm{H}_{2} \mathrm{O}_{2}$ formation was quantified by the slope of the increasing absorbance at $550 \mathrm{~nm}$, $\varepsilon_{550 \mathrm{~nm}}=54,000 \mathrm{~L} \mathrm{~mol}^{-1} \mathrm{~cm}^{-1}$.

\section{Hypochlorous acid ( $\mathrm{HOCl})$}

Hypochlorous acid $(\mathrm{HOCl})$ was quantified in this same system at the end point of two hours of incubation at $37{ }^{\circ} \mathrm{C} .{ }^{27}$ After being incubated with taurine sol. (5 $\left.\mathrm{mmol} \mathrm{L}^{-1}\right)$, diethyl selenodiglycolate sol. $(0,0.5$, $1.0,10,25$ or $\left.50 \mu \mathrm{mol} \mathrm{L} \mathrm{L}^{-1}\right)$ in PBS/glucose solution and activated with PMA (100 $\left.\mathrm{ng} \mathrm{mL}^{-1}\right)$, cells were centrifuged at 1400 rotations per minute (rpm) for $10 \mathrm{~min}$. Cell supernatants $(100 \mu \mathrm{L})$ were diluted in $400 \mu \mathrm{L}$ of PBS/glucose and TNB $\left(80 \mu \mathrm{mol} \mathrm{L} \mathrm{L}^{-1}\right)$ was added to the solution and allowed to react for $15 \mathrm{~min}$. Quantification of $\mathrm{HOCl}$ was indirectly measured by formation of taurine chloroamine and oxidation of TNB to the colorless product dithionitrobenzoic acid (DTNB). The loss in TNB was quantified at $412 \mathrm{~nm} ; \varepsilon_{412 \mathrm{~nm}}=13,600 \mathrm{~L} \mathrm{~mol}^{-1} \mathrm{~cm}^{-1}$.

\section{Cell viability}

Differentiated HL-60 cells $\left(2 \times 10^{6}\right)$ were incubated in the absence or presence of different concentrations of diethyl selenodiglycolate sol. $(0.5,1.0,10,25,50$ or $100 \mu \mathrm{M})$ or staurosporine (Stp) $\left(1 \mu \mathrm{mol} \mathrm{L} \mathrm{L}^{-1}\right.$, positive control) at $37{ }^{\circ} \mathrm{C}$ for 24 and $48 \mathrm{~h}$ in 6-well plates with a total volume of $2 \mathrm{~mL}$ growth media. After this period, a total of $1 \times 10^{6}$ cells were centrifuged at $1400 \mathrm{rpm}$ for $10 \mathrm{~min}$ and the pellet was suspended in PBS/glucose sol. and incubated with $10 \mu \mathrm{g} \mathrm{mL} \mathrm{m}^{-1}$ PI sol. for $15 \mathrm{~min}$. The fluorescence of labeled cells was detected using $\lambda \mathrm{ex}=535 \mathrm{~nm}, \lambda \mathrm{em}=620 \mathrm{~nm}$ in a BD Biosciences flow cytometry (San Jose, CA, USA). ${ }^{28}$

\section{Computational details}

The calculations were performed using the Gaussian 09 package..$^{29}$ The structures of the studied compounds were optimized without any symmetry constraints, and the resulting structures were assessed using vibrational frequency analysis to probe whether they represent true minimum-energy geometries. We performed the geometry optimizations and frequency calculations using the hybrid functional B3PW9130 and the hybrid density functional wB97XD, including empirical atomic-pairwise dispersion corrections, following the Grimme's D2 dispersion scheme, ${ }^{31}$ along with the split-valence basis sets $6-311+\mathrm{G}^{*}$ and $6-311++G^{* *} .32$ Computational studies were done both, in the gas phase and with implicit effects from $\mathrm{H}_{2} \mathrm{O}$ (dielectric constant $\varepsilon=78.3553$ ), $\mathrm{C}_{6} \mathrm{H}_{6}$ (benzene, $\varepsilon=2.2706$ ), and $\mathrm{C}_{6} \mathrm{H}_{5} \mathrm{CH}_{3}$ (toluene, $\varepsilon=2.3741$ ), using the self-consistent reaction field IEF-PCM (integral equation formalism-polarizable continuum model) method $^{33}$ (the UFF default model used in the Gaussian 09 package, with the electrostatic scaling factor $\alpha$ set to 1.0). The reaction energies, in $\mathrm{kcal} \mathrm{mol}^{-1}$, were calculated by the following formula:

$\Sigma \mathrm{E}=\Sigma \mathrm{E} 0($ products $)-\Sigma \mathrm{E} 0($ reactants $)$

where $\mathrm{E} 0$ are the electronic energies. 


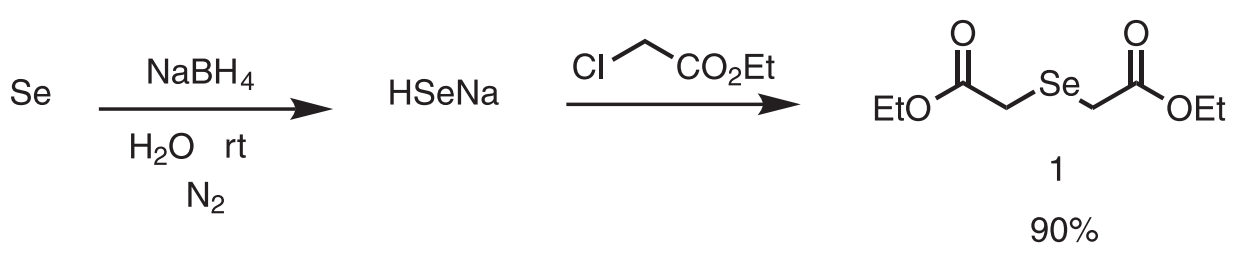

Scheme 1. Preparation of diethyl selenodiglycolate from elemental selenium (1.0 g; $12.6 \mathrm{mmol})$ in $\mathrm{H}_{2} \mathrm{O}(10 \mathrm{~mL})$, sodium borohydride (1.0 g; $26.5 \mathrm{mmol}$, in $10 \mathrm{~mL}$ of $\left.\mathrm{H}_{2} \mathrm{O}\right)$ and neat ethyl chloroacetate $(3.08 \mathrm{~g} ; 25.2 \mathrm{mmol})$ under ambient temperature.

\section{Results and Discussion}

Aiming to prepare synthetically simple organic selenides, we imagined a one-step procedure to prepare a seleno-carboxylic acid derivative. The simplest representative we established as the target compound is the symmetrical diethyl selenodiglycolate. To prepare this compound, the aqueous-soluble nucleophilic selenium reagent $(\mathrm{HSeNa})$ was generated in situ by reacting elemental selenium $(\mathrm{Se})$ with sodium borohydride $\left(\mathrm{NaBH}_{4}\right)$ in water, followed by the reaction with commercially available ethyl chloroacetate, rendering diethyl selenodiglycolate (1) in $90 \%$ yield (Scheme 1 ).

After adjustment in the reaction conditions, diethyl selenodiglycolate was prepared in a single step in a $10 \mathrm{~g}$-scale with the same reproducibility and yield. The product was isolated from the aqueous phase by extracting it with ethyl acetate followed by its concentration under vacuum. Compound 1 was incubated with $\mathrm{HOCl}$ in order to verify its antioxidant capacity. It was observed a very fast consumption of $\mathrm{HOCl}$ (data not shown) and then the kinetic calculations of this reaction were done.

The kinetic was based in a competition assay between diethyl selenodiglycolate and Fmoc-Met for HOCl. The known constant rate of the reaction of Fmoc-Met and $\mathrm{HOCl}$ $\left(1.3 \times 10^{8} \mathrm{M}^{-1} \mathrm{~s}^{-1}\right)$ has been used to find out the constant rate of $\mathrm{HOCl}$ with well-known antioxidants. ${ }^{19}$ In this assay, different concentrations of diethyl selenodiglycolate were incubated with fixed concentrations of Fmoc-Met and $\mathrm{HOCl}$ and the formation of Fmoc-MetSO was quantified by UPLC.

Figure 1 shows the linear relation between the maximum production of Fmoc-MetSO in absence and presence of different concentrations of diethyl selenodiglycolate ( $y$ axis) and the total concentration of diethyl selenodiglycolate ( $x$ axis) (details are explicit in equations 1 and 2 in the Experimental section).

The second order constant was calculated by the competition between Fmoc-Met and diethyl selenodiglycolate for $\mathrm{HOCl}$. Fmoc-MetSO was quantified in the absence $\left(\right.$ yield $_{\max }$ ) and in presence of different concentrations of scavenger ( yield $_{\text {scavenger }}$ ).

The slope of this linear regression gives the $\mathrm{k}_{\text {scavenger }}=7 \times 10^{7} \mathrm{M}^{-1} \mathrm{~s}^{-1}$, i.e., the $\mathrm{k}$ value for the oxidation

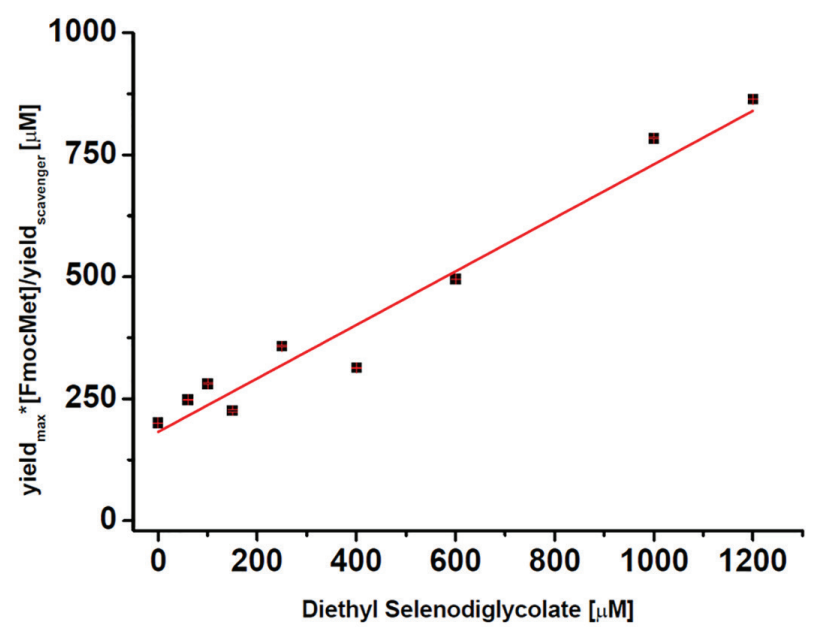

Figure 1. Kinetic data of the reaction of diethyl selenodiglycolate with $\mathrm{HOCl}$.

of diethyl selenodiglycolate by $\mathrm{HOCl}$. This constant was similar to the ones found for the reaction of $\mathrm{HOCl}$ with other seleno derivatives and with glutathione ${ }^{19-34}$ $\left(1.1 \times 10^{8} \mathrm{M}^{-1} \mathrm{~s}^{-1}\right)$, showing that diethyl selenodiglycolate might be a competitive antioxidant in biological systems to scavenger $\mathrm{HOCl}$ and to maintain the levels of untouched glutathione.

In order to identify the product of the oxidation of $\mathbf{1}$ by HOCl (Scheme 2), ${ }^{77} \mathrm{Se}$ NMR and HRMS spectra, of a freshly prepared solution of $\mathbf{1}$ and $\mathrm{NaOCl}$ sol. (2 equiv.) in DMSO, were acquired (Figure 2).

The ${ }^{77} \mathrm{Se}$ NMR spectrum of compound $\mathbf{1}$ (diethyl selenodiglycolate) presented a single signal in $\delta 244.7 \mathrm{ppm}$ and after treating the DMSO sol. of diethyl selenodiglycolate with $\mathrm{NaOCl}$, this signal was suppressed giving rise to a new intense signal in $\delta 1,199.37 \mathrm{ppm}$, along another attributed to the basic ester hydrolysis product. This freshly prepared solution was also analyzed by HRMS. The presence of the oxidized product was corroborated, as it can be seen in Figure $2\left(\mathrm{~m} / \mathrm{z}\right.$, calcd. $[\mathrm{M}+\mathrm{Na}]^{+}$: 292.9904; found: 292.9891).

The ability of $\mathrm{H}_{2} \mathrm{O}_{2}$ and $\mathrm{ClO}^{-}$(hipochlorite anion) to oxidize diethyl selenodiglycolate was studied through theoretical calculations and in comparison with Fmoc-Met. The summarized oxidation energy values are presented in SI section. B3PW91/6-311+G* and B3PW91/6-311++G** computational approaches gave essentially the same 


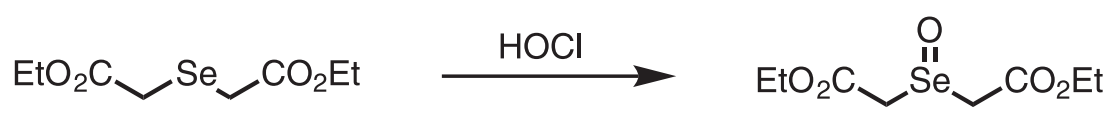

Scheme 2. HOCl-promoted oxidation of diethyl selenodiglycolate.
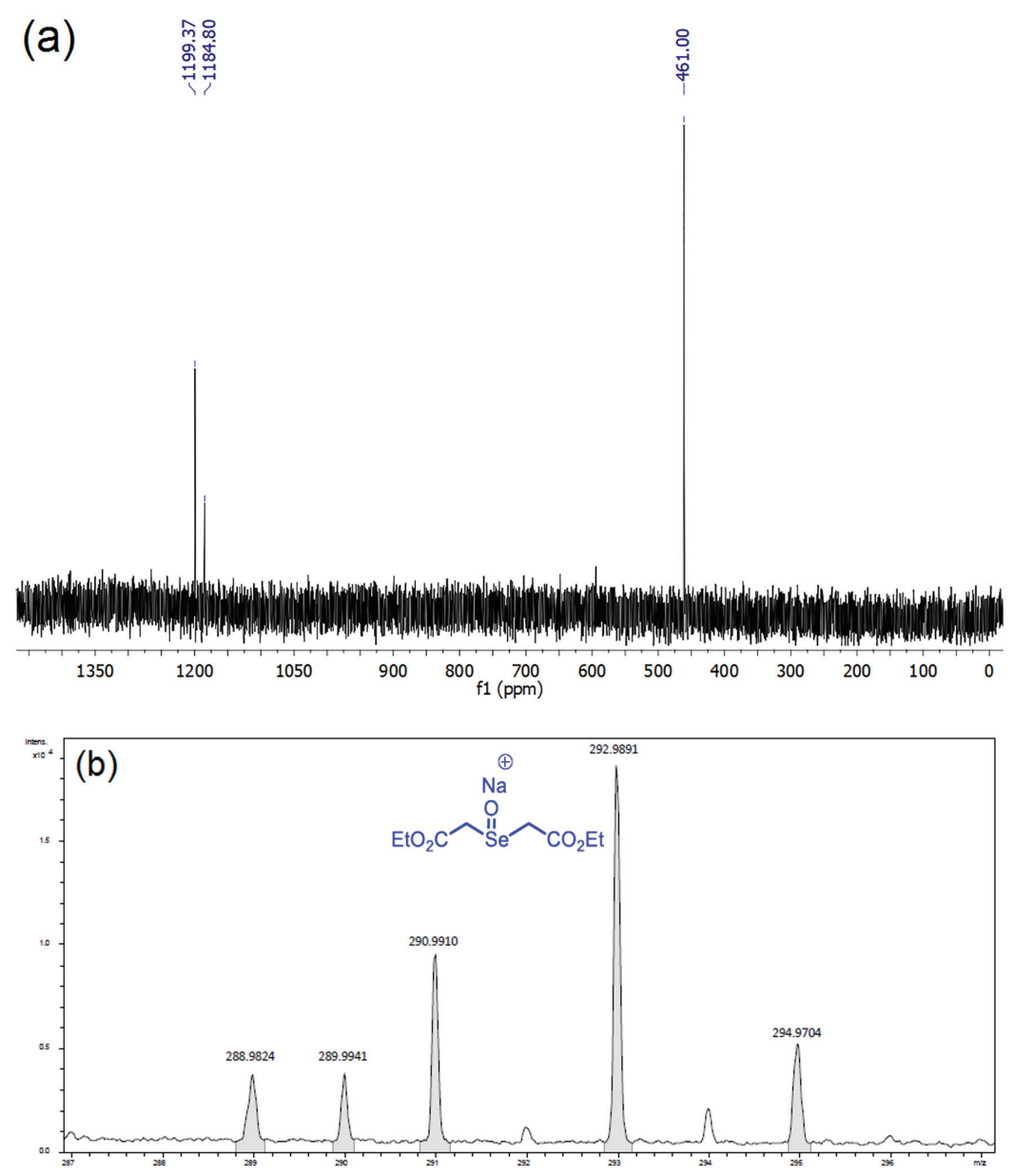

Figure 2. (a) ${ }^{77} \mathrm{Se}$ NMR spectra ( $38 \mathrm{MHz}, \mathrm{DMSO}-d_{6}$ ) of oxidation product from diethyl selenodiglycolate ( $51 \mathrm{mg}$; $0.2 \mathrm{mmol}$ in $500 \mu \mathrm{L}$ of deuterated DMSO), selenoxide prepared by oxidation mediated by $\mathrm{NaOCl}\left(0.9 \mathrm{~mol} \mathrm{~L}^{-1} ; 444 \mu \mathrm{L}\right)$; (b) high resolution mass spectra of selenoxide, mediated by oxidation of $\mathrm{NaOCl}$.

reaction energies for the two considered reaction stages for compounds diethyl selenodiglycolate and Fmoc-Met. The calculations performed with the wB97XD/6-311+G* approach gave slightly larger reaction energies (by ca. 3-5 $\mathrm{kcal} \mathrm{mol}^{-1}$ ) for the oxidation of the two compounds, selenoxide and Fmoc-MetSO with $\mathrm{ClO}^{-}$, compared to the calculations performed with the B3PW91/6-311+G* and B3PW91/6-311++G** approaches. For both, diethyl selenodiglycolate and Fmoc-Met, the reaction steps considered were calculated to be highly exothermic in the gas phase as well as in the polar (water) and non-polar (benzene and toluene) implicit solvents. Generally, for the Fmoc-methionine sulfoxide the oxidation energies were calculated and the values are higher than for the Fmocmethionine, especially for diethyl selenodiglycolate.

We next evaluated whether diethyl selenodiglycolate would scavenge $\mathrm{HOCl}$ in a cell system. The stimulation of
dHL-60 with PMA induces the phosphorylation of cytosolic NADPH (nicotinamide adenine dinucleotide phosphate) oxidase subunits and their assemblage in the plasma membrane. This event triggers superoxide production, which is the first step in the inflammatory oxidative burst. ${ }^{35}$ The anion radical superoxide undergoes the spontaneous (ca. $10^{5} \mathrm{M}^{-1} \mathrm{~s}^{-1}$ ) and catalyzed (ca. $10^{9} \mathrm{M}^{-1} \mathrm{~s}^{-1}$ ) dismutation to hydrogen peroxide, ${ }^{36}$ the first substrate for the inflammatory enzyme myeloperoxidase. This enzyme uses $\mathrm{H}_{2} \mathrm{O}_{2}$ to oxidize $\mathrm{Cl}^{-}$to $\mathrm{HOCl} / \mathrm{ClO}^{-}$, an important bactericidal agent but also a key molecule responsible for oxidative tissue damage. ${ }^{35}$

Our results showed an increase in superoxide, hydrogen peroxide and hypochlorous acid in dHL-60 stimulated with PMA (Figure 3). It is noted that diethyl selenodiglycolate dose-dependently removed the $\mathrm{HOCl}$ produced by these cells (Figure 3a). The half maximal inhibitory concentration 
(a)

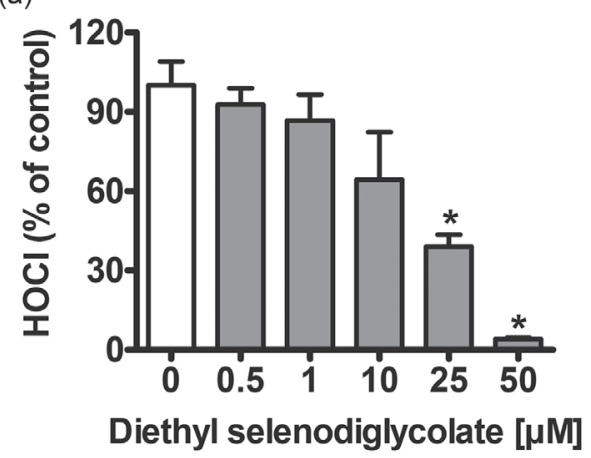

(c)

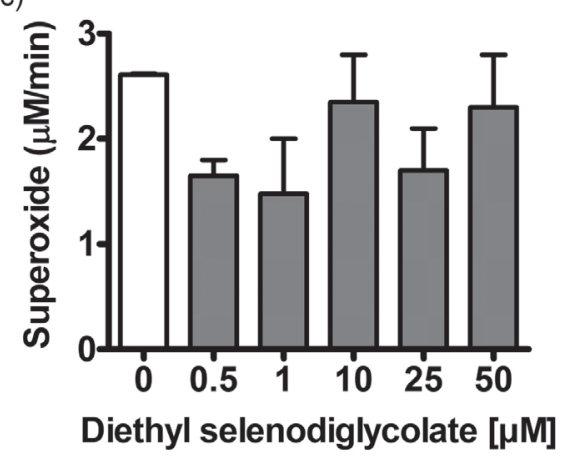

(b)

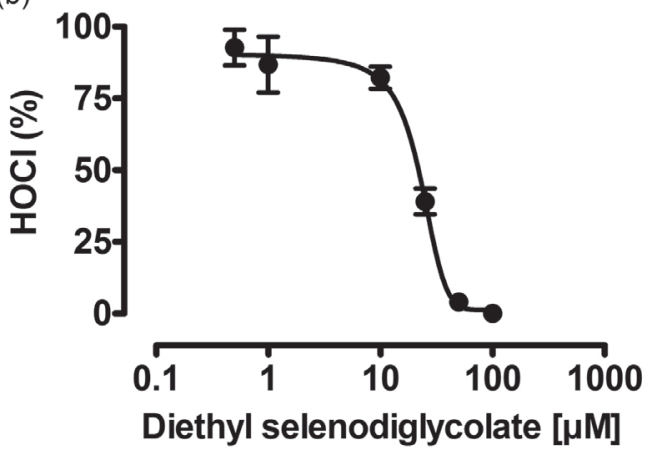

(d)

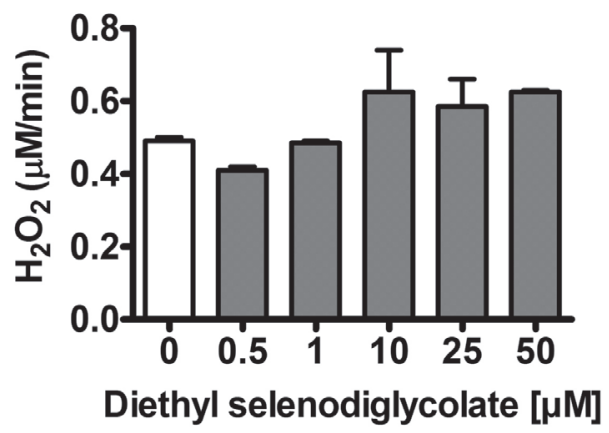

Figure 3. Scavenger effect of diethyl selenodiglycolate against oxidants produced in the inflammatory oxidative burst in dHL-60. (a, b) HOCl; (c) superoxide anion radical; (d) hydrogen peroxide. (b) $\mathrm{IC}_{50}$ was performed by nonlinear regression analysis. dHL-60 cells $\left(1 \times 10^{6}\right)$ were incubated in the absence or presence of different concentrations of diethyl selenodiglycolate $(0.5,1.0,10,25$ and $50 \mu \mathrm{M})$ in PBS/glucose at $37^{\circ} \mathrm{C}$ and activated with PMA $\left(100 \mathrm{ng} \mathrm{mL}^{-1}\right)$. Each bar represents the average \pm standard error of three independent experiments. Statistical analyzes were performed using one-way analysis of variance (ANOVA) followed by Bonferroni's post-test. The asterisk denotes a significant difference $p<0.05$ when compared to the control group.

$\left(\mathrm{IC}_{50}\right)$ and the respective confidence interval for the consumption of $\mathrm{HOCl}$ was 23.07 (19.03-27.97) $\mu \mathrm{mol} \mathrm{L} \mathrm{L}^{-1}$ (Figure 3b).

Once the production of $\mathrm{HOCl}$ in these cells is directly dependent on the levels of superoxide and hydrogen peroxide, we verified if the decreasing in $\mathrm{HOCl}$ occasioned by diethyl selenodiglycolate could also be due to a scavenger effect upon superoxide and hydrogen peroxide. As demonstrated in Figures $3 c$ and $3 d$, selenide did not affect superoxide and hydrogen peroxide levels, showing a specific effect upon $\mathrm{HOCl}$. It is noteworthy to mention that this system only measures the oxidants that are produced at, or diffused to the extracellular space; therefore, we cannot exclude a reducing effect of diethyl selenodiglycolate upon hydrogen peroxide in reactions catalyzed by intracellular peroxidases, like glutathione peroxidase.

In order to ensure that the selenide would not be toxic to cells, we conducted cell viability assays using PI. PI does not cross cell membranes and its binding to deoxyribonucleic acid (DNA) means plasma membrane disruption. Figure 4 illustrates the histograms of control dHL-60 cells (Figure 4A), staurosporine positive control cells (Figure 4B) and cells treated with compound $\mathbf{1}$
(Figure 4C). Two different gates can be visualized, one indicating viable cells (b) and other indicating the dead cells (a). The intensity of PI fluorescence is much higher in staurosporine treated than in control and in cells treated with diethyl selenodiglycolate (Figure 4D). Diethyl selenodiglycolate does not affect cell viability at any tested concentration in 24 (Figure 4E) or $48 \mathrm{~h}$ (Figure 4F).

\section{Conclusions}

In summary, we demonstrated a single step, ecofriendly and high yielding synthesis of a small and effective $\mathrm{HOCl}$-reactive selenide from commercially available starting materials. The production of $\mathrm{HOCl}$ by inflammatory cells is crucial to kill microorganisms. ${ }^{37}$ However, excessive production of $\mathrm{HOCl}$ either in sterile conditions or in unsolved inflammation is associated with tissue damage and chronic inflammatory diseases, including arthritis, ${ }^{38}$ cystic fibrosis ${ }^{39}$ and neurodegenerative ${ }^{40,41}$ and cardiovascular disease. ${ }^{42}$ The constant rate reaction of diethyl selenodiglycolate with $\mathrm{HOCl}$ was measured comparing to a standardized sulfide (Fmoc-Met) demonstrating a very high kinetic constant. The oxidant-scavenger capacity of selenide was 
(A)

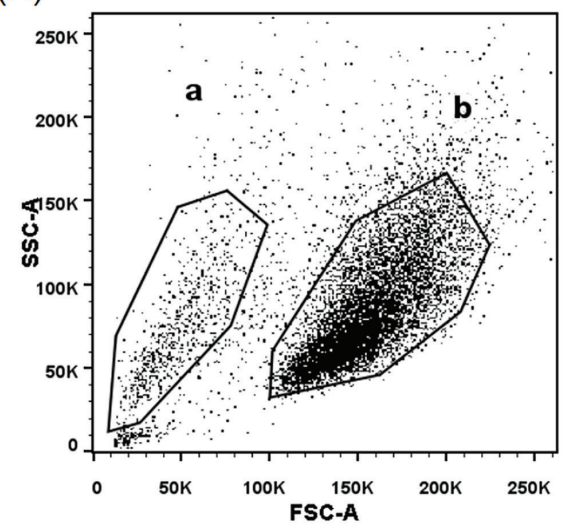

(C)

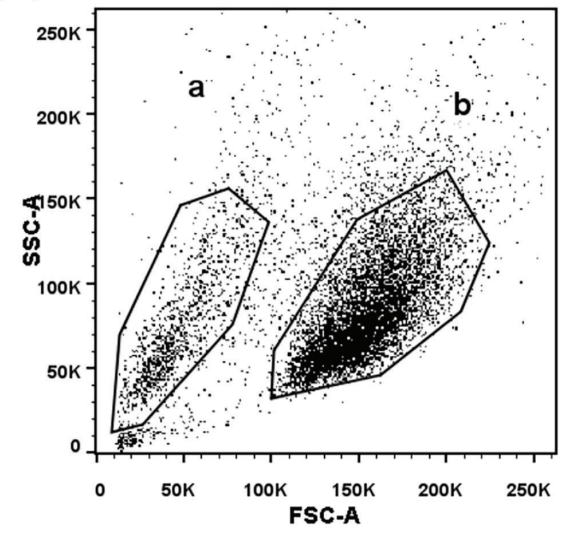

(E)

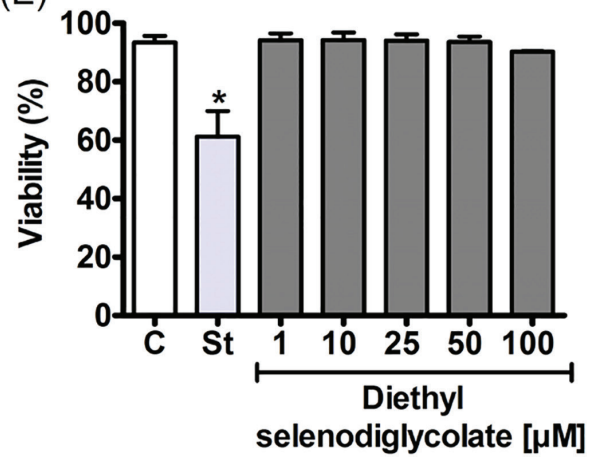

(B)

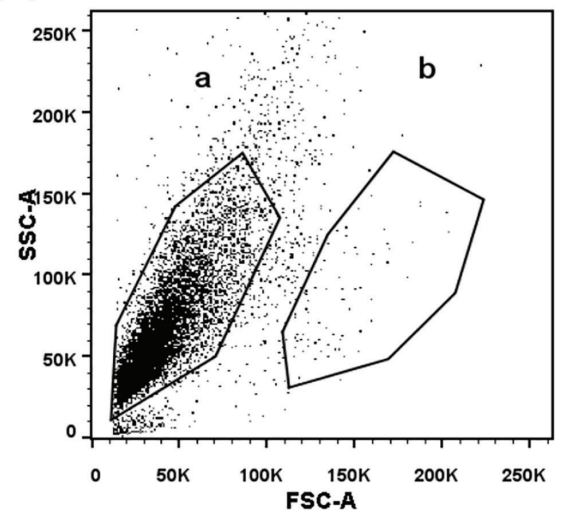

(D)

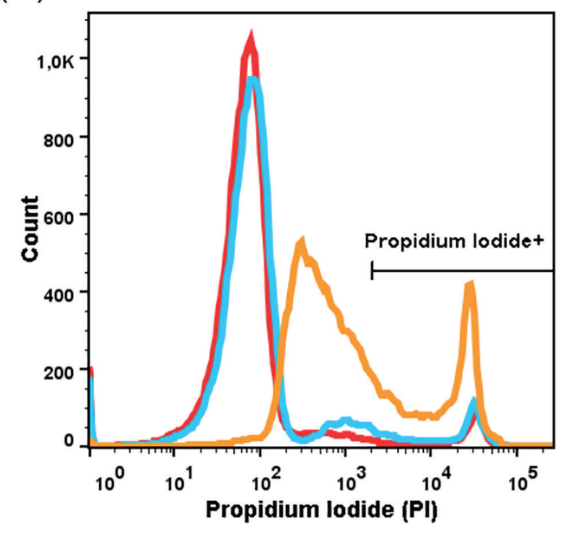

(F)

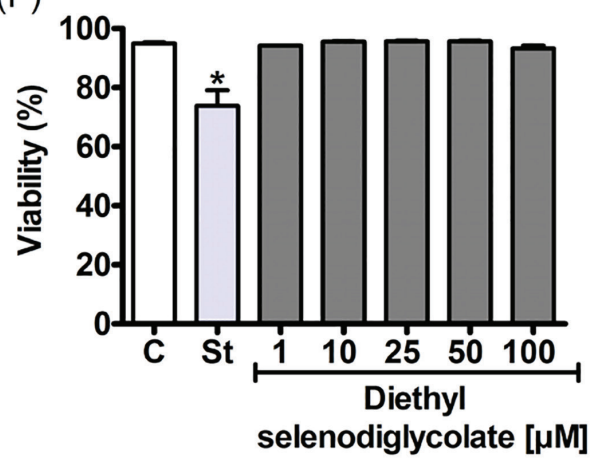

Figure 4. Effect of compound diethyl selenodiglycolate in cell viability. Cell viability was measured using propidium iodide (PI) staining in a flow cytometry. The gate selection strategy was defined across populations using dHL-60 treated with staurosporine for non-viable cell gate selection (a) and non-treated dHL-60 as standard to select viable cell gates (b). Representative graphs of cell populations in (A) dHL-60; (B) dHL-60 + staurosporine (1 $\mu$ M); (C) dHL60 + diethyl selenodiglycolate $(100 \mu \mathrm{M})$; (D) fluorescence intensity of PI in dHL-60 alone (red line), dHL-60 + staurosporine (orange line) and dHL-60 + diethyl selenodiglycolate (blue line). Percentage of cell viability (E) 24 or (F) $48 \mathrm{~h}$ after incubation with staurosporine (St) or diethyl selenodiglycolate. Each bar represents the average \pm standard error of three independent experiments. Statistical analysis was performed using one-way ANOVA followed by Bonferroni's post-test. The asterisk denotes a significant difference $p<0.05$ when compared to the control group (C).

demonstrated, by performing experiments with dHL-60 cells, presenting high selectivity to $\mathrm{HOCl}$ produced by dHL-60 cells, in presence of superoxide and hydrogen peroxide. Additionally, this compound presented high potential for in vivo applications since it does not demonstrate any cytotoxicity through dHL-60 cells.

\section{Supplementary Information}

Supplementary data (NMR spectra and theoretical approaches) are available free of charge at http://jbcs.sbq.org.br as PDF file. 


\section{Acknowledgments}

We acknowledge financial support from the State of São Paulo Research Foundation (FAPESP-CEPID-Redoxoma 2013/07937-8). M. F. P.-B. acknowledges the National Council for Scientific and Technological Development (CNPq), process number (141779/2014-4), Brazil. R. P. S. also thanks FAPESP for the scholarship support (2015/21563-9).

\section{Author Contributions}

Marcos F. Pinatto-Botelho was responsible for the investigation, methodology and writing original draft; Railmara P. da Silva for the investigation and methodology; Lilian Giroldo for the writing review and editing; Marcos V. L. R. Archilha for the data curation and formal analysis; Aleksey E. Kuznetsov for the data curation and software; Flávia C. Meotti for the supevision, writing original draft, funding acquisition; and Alcindo A. dos Santos for the supevision, writing original draft and funding acquisition.

\section{References}

1. Jacob, C.; Giles, G. I.; Giles, N. M.; Sies, H.; Angew. Chem., Int. Ed. 2003, 42, 4742.

2. Gromer, S.; Eubel, J. K.; Lee, B. L.; Jacob, J.; Cell. Mol. Life Sci. 2005, 62, 2414.

3. Reich, H. J.; Hondal, R. J.; ACS Chem. Biol. 2016, 11, 821.

4. Turner, D. C.; Stadtman, T. C.; Arch. Biochem. Biophys. 1973, $154,366$.

5. Terry, N.; Zayed, A. M.; de Souza, M. P.; Tarun, A. S.; Annu. Rev. Plant Physiol. Plant Mol. Biol. 2000, 51, 401.

6. Kápolna, E.; Hillestrøm, P. R.; Laursen, K. H.; Husted, S.; Larsen, E. H.; Food Chem. 2009, 115, 1357.

7. Comasseto, J. V.; J. Braz. Chem. Soc. 2010, 21, 2027.

8. Bach, T. G.; Organoselenium Chemistry: A Practical Approach, vol. 1, $1^{\text {st }}$ ed.; Elsevier: Oxford, UK, 2003.

9. Santi, C.; Tidei, C.; Scalera, C.; Piroddi, M.; Galli, F.; Curr. Chem. Biol. 2013, 7, 25.

10. Müller, A.; Cadenas, E.; Graf, P.; Sies, H.; Biochem. Pharmacol. 1984, 33, 3235.

11. Yamaguchi, T.; Sano, K.; Takakura, K.; Saito, I.; Shinohara, Y.; Asano, T.; Yasuhara, H.; Stroke 1998, 29, 12.

12. Sies, H.; Free Radical Biol. Med. 1993, 14, 313.

13. Selvakumar, K.; Shah, P.; Singh, H. B.; Butcher, R. J.; Chem. - Eur. J. 2011, 17, 12741.

14. Back, T. G.; Dyck, B. P.; J. Am. Chem. Soc. 1997, 119, 2079.

15. Arai, K.; Kumakura, F.; Takahira, M.; Sekiyama, N.; Kuroda, N.; Suzuki, T.; Iwaoka, M.; J. Org. Chem. 2015, 80, 5633.
16. Meotti, F. C.; Stangherlin, E. C.; Zeni, G.; Nogueira, C. W.; Rocha, J. B. T.; Environ. Res. 2004, 94, 276.

17. Nogueira, C. W.; Zeni, G.; Rocha, J. B. T.; Chem. Rev. 2004, 104,6255 .

18. Streinbrenner, H.; Al-Quraishy, S.; Dkhil, M. A; Wunderlich, F.; Sies, H.; Adv. Nutr. 2015, 6, 73.

19. Storkey, C.; Pattison, D. I.; White, J. M.; Schiesser, C. H.; Davies, M. J.; Chem. Res. Toxicol. 2012, 25, 2589.

20. Carroll, L.; Davies, M. J.; Pattison, D. I.; Free Radical Res. 2015, 49, 750 .

21. Skaff, O.; Pattison, D. I.; Morgan, P. E.; Bachana, R.; Jain, V. K.; Priyadarsini, K. I.; Davies, M. J.; Biochem. J. 2012, 441, 305.

22. Armarego, W. L. F.; Chai, C. L.; Purification of Laboratory Chemicals, vol. 1, $7^{\text {th }}$ ed.; Elsevier: Oxford, UK, 2003.

23. Morris, J. C.; J. Phys. Chem. 1966, 70, 3798.

24. Klayman, D. L.; Griffin, T. S.; J. Am. Chem. Soc. 1973, $2,197$.

25. Gazis, D.; Glass, J.; Schwartz, I. L.; Stavropoulos, G.; Theodoropoulos, D.; Int. J. Pept. Protein Res. 1989, 34, 353.

26. Pick, E.; Mizel, D.; J. Immunol. Methods 1981, 46, 211.

27. Kettle, A. J.; Winterbourn, C. C.; Methods Enzymol. 1994, 233, 502.

28. Riccardi, C.; Nicoletti, I.; Nat. Protoc. 2006, 1, 1458.

29. Frisch, M. J.; Trucks, G. W.; Schlegel, H. B.; Scuseria, G. E.; Robb, M. A.; Cheeseman, J. R.; Scalmani, G.; Barone, V.; Petersson, G. A.; Nakatsuji, H.; Li, X.; Caricato, M.; Marenich, A.; Bloino, J.; Janesko, B. G.; Gomperts, R.; Mennucci, B.; Hratchian, H. P.; Ortiz, J. V.; Izmaylov, A. F.; Sonnenberg, J. L.; Williams-Young, D.; Ding, F.; Lipparini, F.; Egidi, F.; Goings, J.; Peng, B.; Petrone, A.; Henderson, T.; Ranasinghe, D.; Zakrzewski, V. G.; Gao, J.; Rega, N.; Zheng, G.; Liang, W.; Hada, M.; Ehara, M.; Toyota, K.; Fukuda, R.; Hasegawa, J.; Ishida, M.; Nakajima, T.; Honda, Y.; Kitao, O.; Nakai, H.; Vreven, T.; Throssell, K.; Montgomery Jr., J. A.; Peralta, J. E.; Ogliaro, F.; Bearpark, M.; Heyd, J. J.; Brothers, E.; Kudin, K. N.; Staroverov, V. N.; Keith, T.; Kobayashi, R.; Normand, J.; Raghavachari, K.; Rendell, A.; Burant, J. C.; Iyengar, S. S.; Tomasi, J.; Cossi, M.; Millam, J. M.; Klene, M.; Adamo, C.; Cammi, R.; Ochterski, J. W.; Martin, R. L.; Morokuma, K.; Farkas, O.; Foresman, J. B.; Fox, D. J.; Gaussian 09, Revision A.02; Gaussian, Inc., Wallingford, CT, 2016.

30. Becke, A. D.; J. Chem. Phys. 1993, 98, 5648.

31. Grimme, S.; J. Comput. Chem. 2006, 27, 1787.

32. Raghavachari, K.; Binkley, J. S.; Seeger, R.; Pople, J. A.; J. Chem. Phys. 1980, 72, 650.

33. Cancès, E.; Mennucci, B.; Tomasi, J.; J. Chem. Phys. 1997, 107, 3032.

34. Folkes, L. K.; Candeias, L. P.; Wardman, P.; Arch. Biochem. Biophys. 1995, 323, 120.

35. Davies, M. J.; J. Clin. Biochem. Nutr. 2011, $48,8$.

36. Gray, B.; Carmichael, A. J.; Biochem. J. 1992, 281, 795. 
37. Klebanoff, S. J.; Kettle, A. J.; Rosen, H.; Winterbourn, C. C.; Nauseef, W. M.; J. Leukocyte Biol. 2013, 93, 185.

38. Davies, J. M. S.; Horwitz, D. A.; Davies, K. J. A.; Free Radical Biol. Med. 1993, 15, 637.

39. Van der Vliet, A.; Nguyen, M. N.; Shigenaga, M. K.; Eiserich, J. P.; Marelich, G. P.; Cross, C. E.; Am. J. Physiol.: Lung Cell. Mol. Physiol. 2000, 279, 537.

40. Hazell, L. J.; Arnold, L.; Flowers, D.; Waeg, G.; Malle, E.; Stocker, R.; J. Clin. Invest. 1996, 97, 1535.
41. Kataoka, Y.; Shao, M.; Wolski, K.; Uno, K.; Puri, R.; Tuzcu, E. M.; Hazen, S. L.; Nissen, S. E.; Nicholls, S. J.; Atherosclerosis 2014, 232, 377.

42. Casciaro, M.; Di Salvo, E.; Pace, E.; Ventura-Spagnolo, E.; Navarra, M.; Gangemi, S.; Immun. Ageing 2017, 14, DOI 10.1186/s12979-017-0104-5.

Submitted: October 7, 2019 Published online: January 27, 2020 